\title{
Vitiligo. Diagnostic and therapeutic recommendations of the Polish Dermatological Society
}

\author{
Bielactwo nabyte. Rekomendacje diagnostyczno-terapeutyczne \\ Polskiego Towarzystwa Dermatologicznego
}

Rafal Czajkowski', Waldemar Placek², Iwona Flisiak ${ }^{3}$, Dorota Krasowska ${ }^{4}$, Joanna Maj ${ }^{5}$, Mariola Marchlewicz ${ }^{6}$, Adam Reich ${ }^{7}$, Hanna Wolska ${ }^{8}$, Lidia Rudnicka9

\author{
'Department of Dermatology, Sexually Transmitted Diseases and Immunodermatology, Faculty of Medicine, \\ Ludwik Rydygier Collegium Medicum in Bydgoszcz, Nicolaus Copernicus University in Torun, Poland \\ 2Department of Dermatology, Sexually Transmitted Diseases and Clinical Immunology, University of Warmia and Mazury, Olsztyn, \\ Poland \\ ${ }^{3}$ Department of Dermatology and Venereology, Medical University of Bialystok, Poland \\ ${ }^{4}$ Chair and Department of Dermatology, Venereology and Pediatric Dermatology, Medical University of Lublin, Poland \\ ${ }^{5}$ Department of Dermatology, Venereology and Allergology, Wroclaw Medical University, Poland \\ ${ }^{6}$ Department of Aesthetic Dermatology, Pomeranian Medical University, Szczecin, Poland \\ ${ }^{7}$ Department of Dermatology, University of Rzeszow, Poland \\ ${ }^{8}$ High-Med Specialist Clinic, Warsaw, Poland \\ 'Department of Dermatology, Medical University of Warsaw, Poland
}

'Klinika Dermatologii, Chorób Przenoszonych Drogą Płciową i Immunodermatologii Collegium Medicum w Bydgoszczy Uniwersytetu Mikołaja Kopernika w Toruniu, Polska

${ }^{2}$ Katedra i Klinika Dermatologii, Chorób Przenoszonych Drogą Płciową i Immunologii Klinicznej Uniwersytetu Warmińsko-Mazurskiego w Olsztynie, Polska

${ }^{3}$ Klinika Dermatologii i Wenerologii Uniwersytetu Medycznego w Białymstoku, Polska

${ }^{4}$ Katedra i Klinika Dermatologii, Wenerologii i Dermatologii Dziecięcej Uniwersytetu Medycznego w Lublinie, Polska

${ }^{5}$ Katedra Dermatologii, Wenerologii i Alergologii Uniwersytetu Medycznego we Wrocławiu, Polska

${ }^{6}$ Zakład Dermatologii Estetycznej Pomorskiego Uniwersytetu Medycznego w Szczecinie, Polska

7Zakład i Klinika Dermatologii Uniwersytetu Rzeszowskiego, Polska

${ }^{8}$ High-Med Przychodnia Specjalistyczna w Warszawie, Polska

${ }^{9}$ Klinika Dermatologiczna Uniwersytetu Medycznego w Warszawie, Polska

Dermatol Rev/Przegl Dermatol 2019, 106, I-15 DOI: https://doi.org/l0.5 | |4/dr.2019.83440

\author{
CORRESPONDING AUTHOR/ \\ ADRES DO KORESPONDENCJI: \\ prof. dr hab. n. med. \\ Rafał Czajkowski \\ Klinika Dermatologii, \\ Chorób Przenoszonych \\ Drogą Płciową \\ i Immunodermatologii \\ Collegium Medicum \\ w Bydgoszczy \\ Uniwersytet Mikołaja Kopernika \\ ul. Marii Skłodowskiej-Curie 9 \\ 85-094 Bydgoszcz \\ e-mail: r.czajkowski@cm.umk.pl
}

\begin{abstract}
Vitiligo is an idiopathic chronic dermatosis manifested by depigmented patches of skin due to the loss of normal pigment-producing cells (melanocytes) and pigment (melanin). The disease develops more commonly in genetically predisposed individuals affected by various adverse external and internal factors inducing cellular stress in melanocytes. Cellular stress activates autoimmune and autoinflammatory mechanisms leading to melanocyte destruction. The disorder affects $0.5-4.0 \%$ of the world population, with no predilection for either sex. Manifestations can appear at any age, however in more than half of patients vitiligo starts before the age of 20 years. The course of the disease is varied - from stable cases with small isolated vitiligo patches to the rapid progression of lesions resulting in large areas of the skin being affected. There are multiple methods of treating vitiligo including pharmacological and surgical modalities, and phototherapy. Another essential aspect is patient education. Available treatment methods do not always yield the expected therapeutic effect. The Recommendations contain infor-
\end{abstract}


mation about the diagnosis of vitiligo, and describe the recommended therapeutic methods.

\section{STRESZCZENIE}

Bielactwo nabyte (vitiligo) jest idiopatyczną, przewlekłą dermatozą objawiającą się odbarwionymi plamami pozbawionymi prawidłowych komórek barwnikowych (melanocytów) oraz barwnika (melaniny). Choroba występuje częściej u osób predysponowanych genetycznie, na które zadziałały różne niekorzystne czynniki zewnętrzne i wewnętrzne, indukujące stres komórkowy w melanocytach. Stres komórkowy aktywuje mechanizmy autoimmunologiczne i autozapalne niszczące komórki barwnikowe. Schorzenie stwierdza się u 0,5-4,0\% populacji światowej, z jednakową częstością u obu płci. Choroba może rozpocząć się w każdym wieku, jednak w ponad połowie przypadków rozpoczyna się przed 20. rokiem życia. Przebieg choroby jest zróżnicowany - od przypadków stabilnych $\mathrm{z}$ obecnością pojedynczych zmian bielaczych niewielkich rozmiarów do stanów chorobowych o szybkiej progresji, zajmujących rozległe obszary skóry. Istnieje wiele metod leczenia bielactwa nabytego, m.in. farmakologiczne, chirurgiczne oraz fototerapia. Konieczna jest również odpowiednia edukacja chorego. Dostępne metody nie zawsze przynoszą oczekiwane efekty terapeutyczne. W niniejszych rekomendacjach zawarto informacje dotyczące diagnostyki bielactwa nabytego i rekomendowanych metod terapeutycznych.

Key words: vitiligo, treatment.

Słowa kluczowe: bielactwo nabyte, leczenie.

\section{INTRODUCTION}

Vitiligo is a systemic idiopathic skin disease characterized by the development of well-marginated depigmented spots caused by the loss or dysregulation of melanocyte function [1].

Vitiligo is a relatively common skin disorder affecting $0.5-4.0 \%$ of the general population [2]. Manifestations can appear at any age, however in more than half of patients vitiligo starts before the age of 20 years. The incidence of the disease decreases with increasing age [3]. The prevalence of vitiligo is the same in both sexes. The disease may also affect the nail apparatus (leukonychia), the skin of the scalp (leukotrichia), and mucous membranes [4].

\section{CLINICAL CLASSIFICATION}

According to the Vitiligo Global Issues Consensus Conference (2012) vitiligo can be divided into segmental vitiligo (SV), non-segmental vitiligo (NSV), and unclassified type [5].

Non-segmental vitiligo is the most common type, accounting for $85-90 \%$ of all cases. NSV may begin in childhood but an onset in adulthood is more common. It is characterized by a positive personal and

\section{WPROWADZENIE}

Bielactwo nabyte (vitiligo) jest ogólnoustrojową, idiopatyczną chorobą skóry, charakteryzującą się występowaniem ostro odgraniczonych, odbarwionych plam spowodowanych utratą lub uszkodzeniem funkcji melanocytów [1].

Bielactwo nabyte stwierdza się stosunkowo często, u 0,5-4,0\% ogółu populacji [2]. Schorzenie to występuje $\mathrm{w}$ każdym wieku, jednak w ponad połowie przypadków rozpoczyna się przed 20. rokiem życia, a wraz z wiekiem liczba zachorowań się zmniejsza [3]. Bielactwo nabyte stwierdza się równie często u mężczyzn i kobiet. Choroba może dotyczyć również aparatu paznokciowego (leukonychia), skóry owłosionej głowy (leukotrichia) oraz błon śluzowych [4].

\section{KLASYFIKACJA KLINICZNA}

Zgodnie z Vitiligo Global Issues Consensus Conference - 2012 bielactwo nabyte dzieli się na: bielactwo segmentalne (segmental vitiligo - SV), bielactwo niesegmentalne (non-segmental vitiligo - NSV) oraz bielactwo niesklasyfikowane [5].

Najczęściej występuje typ niesegmentalny (85$90 \%$ ), który może rozpocząć się w dzieciństwie, ale 
family history of autoimmune diseases. Vitiligo lesions develop primarily in areas of trauma (Koebner phenomenon). Surgical treatment in this type of vitiligo has little efficacy, and relapses are common [6]. Non-segmental vitiligo includes several subtypes: focal, mucosal, acrofacial, generalized and universal.

Segmental vitiligo (SV) normally begins in early childhood. It is characterized by a rapid onset and stable course in the majority of cases. Cutaneous lesions tend to have a unilateral distribution. They appear in only a part of the dermatome or involve the entire dermatome (less commonly several dermatomes). They may also be distributed along Blaschko's lines. Vitiligo patches most commonly occur on the face and can be accompanied by leukotrichia. In segmental vitiligo good therapeutic outcomes are achieved with surgical treatment. The SV can be divided into several subtypes including focal, mucosal, unisegmental, bisegmental and multisegmental.

\section{VITILIGO IN CHILDREN}

Children are most commonly affected by the segmental type of vitiligo. The disease appears early in childhood, and it is more prevalent in girls than in boys [7]. In addition to typical locations such as the face and neck, vitiligo lesions in infants are also frequently encountered in the diaper area. In children vitiligo patches usually affect less than $20 \%$ of body surface area [8]. The Koebner phenomenon has been described in both types of vitiligo, more typically in patients with the non-segmental type of the disorder [9]. On account of numerous injuries and abrasions in this group of patients, the Koebner phenomenon occurs commonly, affecting approximately $11.3 \%$ of children with vitiligo. In a proportion of patients NSV is preceded by the development of halo nevus (Sutton's nevus) which is estimated to occur in approximately $1 \%$ of the pediatric population. According to the literature reports the frequency of coexistence of vitiligo and Sutton's nevus ranges from $2.5 \%$ to $34.0 \%$. The involvement of the skin of the scalp is noted in approximately $25 \%$ of children with vitiligo [10].

\section{PATHOGENESIS}

The etiology of vitiligo has not been clearly elucidated. Multiple theories have been proposed regarding the causes of the disorder: genetic, oxidative stress (autotoxicity), autoimmune, autoinflammatory, neurogenic, melanocyte detachment (melanocytorrhagy), apoptotic and multifactorial [1]. Currently, the theory prevails that vitiligo is a multifactorial disease. Individuals with a genetic predisposition develop skin lesions following exposure to specific częściej pojawia się w wieku dorosłym. Charakteryzuje się dodatnim wywiadem osobniczym i rodzinnym w kierunku zaburzeń autoimmunologicznych. Zmiany bielacze występują głównie w miejscach urazu (objaw Koebnera). Leczenie chirurgiczne w tym typie bielactwa cechuje się niewielką skutecznością, częste są też nawroty choroby [6]. Wyróżnia się kilka podtypów tej odmiany: ogniskowy, błon śluzowych, twarzowo-kończynowy, uogólniony, uniwersalny.

Typ segmentalny zazwyczaj rozpoczyna się we wczesnym dzieciństwie. Charakteryzuje się nagłym początkiem i najczęściej stabilnym przebiegiem. Zmiany są zwykle jednostronne, zajmują część lub cały dermatom, rzadziej kilka dermatomów lub układają się wzdłuż linii Blaschko. Plamy bielacze najczęściej zlokalizowane są na twarzy i mogą współistnieć z leukotrichią. W SV dobre efekty terapeutyczne obserwuje się po leczeniu chirurgicznym. Do SV zalicza się podtypy: ogniskowy, błon śluzowych, jedno-, dwu-, wielosegmentalny.

\section{BIELACTWO U DZIECI}

U dzieci częściej występuje typ segmentalny bielactwa nabytego. Rozpoczyna się we wczesnym dzieciństwie, częściej u dziewczynek [7]. Oprócz typowych lokalizacji, takich jak szyja i twarz, u niemowląt zazwyczaj zajęta jest okolica pieluszkowa. W przypadku dzieci zmiany chorobowe zajmują zwykle poniżej 20\% powierzchni skóry [8]. Objaw Koebnera opisywano w obu typach bielactwa, częściej w przypadku pacjentów z NSV [9]. Ze względu na liczne urazy oraz otarcia $w$ tej grupie chorych jest to zjawisko częste i dotyczy około 11,3\% dzieci z bielactwem nabytym. Znamię Suttona, które występuje u około $1 \%$ populacji dziecięcej, może u części chorych poprzedzać rozwój bielactwa typu NSV. Według danych z piśmiennictwa częstość współwystępowania vitiligo i znamienia Suttona wynosi od 2,5\% do 34,0\%. U około $25 \%$ dzieci z bielactwem nabytym zmiany dotyczą skóry owłosionej głowy [10].

\section{PATOGENEZA}

Etiologia choroby wciąż nie jest do końca poznana. Istnieją różne teorie wyjaśniające przyczyny vitiligo: genetyczna, stresu oksydacyjnego (autodestrukcji), autoimmunologiczna, autozapalna, neurogenna, zaburzeń przylegania (melanocytorrhagia), apoptotyczna, wieloczynnikowa [1]. Obecnie najpowszechniej akceptowana jest teoria wieloczynnikowa, zgodnie $\mathrm{z}$ którą plamy bielacze pojawiają się u pacjentów z genetyczną predyspozycją pod wpływem czynników środowiskowych. Okres dojrzewania, ciąża, infekcje o ciężkim przebiegu, stres psychiczny i urazy 
environmental factors. Puberty, pregnancy, severe infections, mental stress and skin injuries may act as vitiligo triggers in genetically predisposed individuals.

Genetic studies conducted to date have focused on patients with NSV. Genome-wide association studies (GWAS) are the "golden standard" in detecting genes responsible for the predisposition to the development of vitiligo. Approximately $90 \%$ of the "suspicious" genes encode immunoregulatory proteins, while the remaining $10 \%$ encode melanocyte proteins [11].

The activation of adverse exogenous and/or endogenous factors in genetically predisposed individuals induces cellular stress in melanocytes and stimulates autoimmune and autoinflammatory processes. Induction of cellular response is a necessary and sufficient precondition for the development of vitiligo. Particular importance is attributed to IFN- $\gamma$, CXCR3 receptors and CXCL9-11 chemokines. The binding of IFN- $\gamma$ to its receptor (IFN- $\gamma$ R) on keratinocytes activates the JAK-STAT signaling pathway, leading to the release of the chemokine CXCL10. CXCL10 promotes the migration of autoreactive T cells (CD8 +) by attaching to their receptor (CXCR3), which exacerbates inflammation via the positive feedback mechanism.

According to the autoinflammatory theory, cellular stress contributes to the formation of the so-called damage-associated molecular patterns (DAMPs), which activates dendritic cells producing proinflammatory cytokines. The heat shock protein HSP70i is the main molecular pattern involved in the pathogenesis of this dermatosis. Chemically-induced cellular stress also intensifies the synthesis of the receptor NLRP3 participating in the activation of the inflammasome or directly the cytokine IL-1 $\beta$. Overexpression of the gene encoding the receptor NLRP1 (Langerhans cells) leads to the activation of inflammasome and induces the conversion of pro-IL-1 $\beta$ into active IL-1 $\beta$, which is involved in the pathogenesis and progression of vitiligo [12].

\section{DIAGNOSIS}

The diagnosis of vitiligo is based primarily on the results of physical examination and patient history, and in uncertain cases also on the findings of additional examinations.

History taking should include patient age, sex, genetic history, history of autoimmune diseases, ethnicity, psychological profile, onset of the disease, its course and degree of stability (stable vitiligo is defined as no new lesions and no progression of existing lesions for 6 months), exposure to factors that may potentially trigger or exacerbate vitiligo such as stress, systemic medications (chloroquine, skóry są czynnikami, które mogą u osób predysponowanych wywołać bielactwo nabyte.

Przeprowadzone dotychczas badania genetyczne dotyczą chorych z NSV. Badania asocjacyjne w skali genomu (genome-wide association studies - GWAS) stanowią złoty standard w wykrywaniu genów odpowiedzialnych za predyspozycję do rozwoju bielactwa nabytego. W przybliżeniu $90 \% \mathrm{z}$,podejrzanych" genów koduje białka immunoregulatorowe, natomiast pozostałe $10 \%$ - białka melanocytów [11].

W wyniku zadziałania niekorzystnych czynników egzogennych i/lub endogennych u osób predysponowanych genetycznie dochodzi do indukcji stresu komórkowego w melanocytach i aktywacji procesów autoimmunologicznych oraz autozapalnych. Indukcja odpowiedzi komórkowej jest konieczna i wystarczająca do rozwoju bielactwa nabytego. Szczególne znaczenie ma interferon $\gamma$ (IFN- $\gamma$ ), receptory CXCR3 oraz chemokiny CXCL9-11. Połączenie IFN- $\gamma$ z jego receptorem (IFN- $\gamma \mathrm{R}$ ) umieszczonym na keratynocytach aktywuje droge sygnałową JAK-STAT, co prowadzi do uwolnienia chemokiny CXCL10. CXCL10 promuje migrację autoreaktywnych komórek T (CD8+), przyłączając się do ich receptora (CXCR3), co nasila stan zapalny na drodze dodatniego sprzężenia zwrotnego.

Według teorii autozapalnej stres komórkowy przyczynia się do produkcji tzw. wzorców molekularnych związanych z uszkodzeniem (DAMPs), co aktywuje komórki dendrytyczne produkujące cytokiny prozapalne. Białko szoku cieplnego HSP70i jest głównym wzorcem molekularnym zaangażowanym w patogenezę tej dermatozy. Indukowany chemicznie stres komórkowy nasila również syntezę receptora NLRP3 biorącego udział w aktywacji inflammasomu lub bezpośrednio cytokiny IL-1 $\beta$. Stwierdzona nadekspresja genu kodującego receptor NLRP1 (komórki Langerhansa) prowadzi do aktywacji inflammasomu i indukcji przejścia pro-IL-1 $\beta \mathrm{w}$ aktywną IL-1 $\beta$, która bierze udział w patogenezie i progresji bielactwa nabytego [12].

\section{ROZPOZNANIE}

Rozpoznanie bielactwa opiera się przede wszystkim na wynikach badania podmiotowego i przedmiotowego, a w przypadkach wątpliwych - na wynikach badań dodatkowych.

W badaniu podmiotowym należy uwzględnić: wiek, płeć, wywiad genetyczny, wywiad dotyczący chorób autoimmunologicznych, pochodzenie etniczne, profil psychologiczny, początek choroby, jej przebieg i stopień stabilności ( 6 miesięcy bez powiększania się obecnych i pojawiania się nowych plam bielaczych odpowiada postaci stabilnej), narażenie na czynniki, które mogą ujawnić lub zaostrzyć bielactwo nabyte, np. stres, leki stosowane ogólnie (chlorochina, flufe- 
fluphenazine, physostigmine, imatinib), topical medications (imiquimod), infections, injuries (Koebner phenomenon), other comorbidities and their treatment, as well as previous attempts to achieve repigmentation (type and duration of treatment) and their outcome [13].

During the physical examination, the physician assesses the location, color, size, shape and margin of vitiligo patches, and determines the type of repigmentation (follicular, peripheral, mixed), Sutton's nevi, nail apparatus and hair, iris color and its uniformity in both eyes. Also, other clinical manifestations which should be included in the differential diagnosis with vitiligo are assessed (figs. 1 and 2).

\section{ADDITIONAL EXAMINATIONS}

Wood's lamp is a device used for evaluating the extent of skin involvement, particularly in individuals with fair skin types. It facilitates the differential diagnosis of white focal lesions. The lamp emits ultraviolet light A (UVA) at a wavelength of approximately $365 \mathrm{~nm}$. The examination should preferably be performed in a darkened room. Wood's lamp produces a bright reflection of vitiligo patches which makes them appear sharper. Examination under Wood's lamp is less useful in patients with a darker skin phototype [6].

In cases with diagnostic difficulties, histopathological examination of affected skin with no observed melanocytes should be performed (Fontana-Masson staining). Melanocytes identified at the periphery of lesions exhibit features of cytoplasmic vacuolar degeneration, pyknotic nuclei, melanosome aggregation and fatty degeneration. In uncertain cases, the histopathological picture should be analyzed based on the patient's history, physical examination and additional tests (mycological, genetic, immunohistochemical and others) carried out in order to differentiate vitiligo from other diseases [14-17]. Table 1 lists laboratory tests and specialist consultations recommended in the diagnosis of vitiligo.

\section{DIFFERENTIAL DIAGNOSIS}

Figures 1 and 2 present the differential diagnosis of generalized and focal vitiligo patches.

\section{TREATMENT}

There is a wide spectrum of methods for the treatment of vitiligo, however none of them guarantees the repigmentation of depigmented patches. The selection of the potentially most effective treatment modality depends on the patient's age, disease dura- nazyna, fizostygmina, imatynib), leki miejscowe (imikwimod), infekcje, urazy (objaw Koebnera) oraz inne choroby towarzyszące wraz z ich leczeniem, a także dotychczas podejmowane próby uzyskania repigmentacji (rodzaj i czas trwania leczenia) i ich rezultaty [13].

W badaniu przedmiotowym określa się lokalizację, zabarwienie, wielkość, kształt, brzeg plam bielaczych, ocenia się rodzaj repigmentacji (przymieszkowa, obwodowa, mieszana), znamiona Suttona, aparat paznokciowy i owłosienie, kolor tęczówek i ich równobarwność oraz poszukuje się innych objawów klinicznych chorób, z którymi należy różnicować bielactwo nabyte (ryc. 1 i 2).

\section{BADANIA DODATKOWE}

Lampa Wooda jest urządzeniem, które umożliwia ustalanie rozległości zmian skórnych, zwłaszcza u osób o jasnej karnacji, oraz ułatwia diagnostykę różnicową ogniskowych białych plam. Urządzenie emituje promieniowanie ultrafioletowe A (UVA) o długości fali około $365 \mathrm{~nm}$. Badanie najlepiej wykonywać w całkowicie zaciemnionym pomieszczeniu. Lampa Wooda zapewnia jasne odbicie plam bielaczych, co powoduje, że są one bardziej widoczne. W przypadku pacjentów z ciemnym kolorem skóry badanie lampą Wooda jest mniej przydatne [6].

W przypadku trudności diagnostycznych należy wykonać badanie histopatologiczne skóry zmienionej chorobowo, w którym nie obserwuje się komórek barwnikowych (barwienie metodą Fontana-Massona). Melanocyty obecne na obwodzie zmian chorobowych mają cechy zwyrodnienia wodniczkowego cytoplazmy, stwierdza się pyknotyczne jądra, agregację melanosomów oraz zwyrodnienie tłuszczowe. W przypadkach wątpliwych należy analizować obraz histopatologiczny, opierając się na wynikach badania podmiotowego, przedmiotowego i innych badań dodatkowych, takich jak mikologiczne, genetyczne, immunohistochemiczne, wykonywanych w celu zróżnicowania bielactwa nabytego z innymi chorobami [14-17]. W tabeli 1 omówiono badania laboratoryjne i konsultacje specjalistyczne rekomendowane $\mathrm{w}$ diagnostyce bielactwa nabytego.

\section{DIAGNOSTYKA RÓŻNICOWA}

Na rycinach 1 i 2 przedstawiono diagnostykę różnicową plam bielaczych uogólnionych i występujących ogniskowo.

\section{LECZENIE}

Istnieje wiele metod leczenia bielactwa, jednak żadna nie daje pewności uzyskania repigmentacji plam bielaczych. Wybór potencjalnie najefektywniejszego 


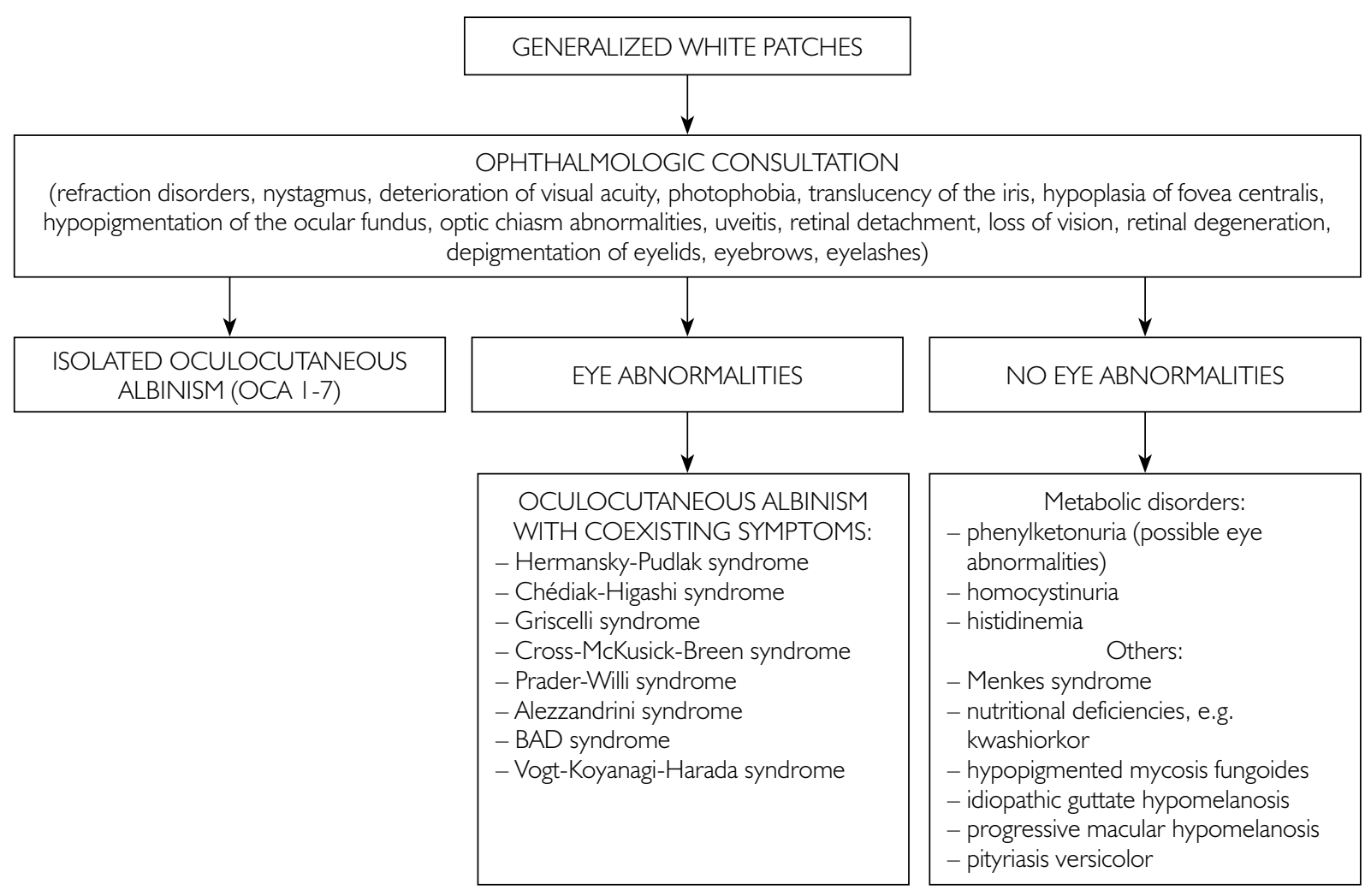

Figure I. Differential diagnosis of generalized vitiligo patches

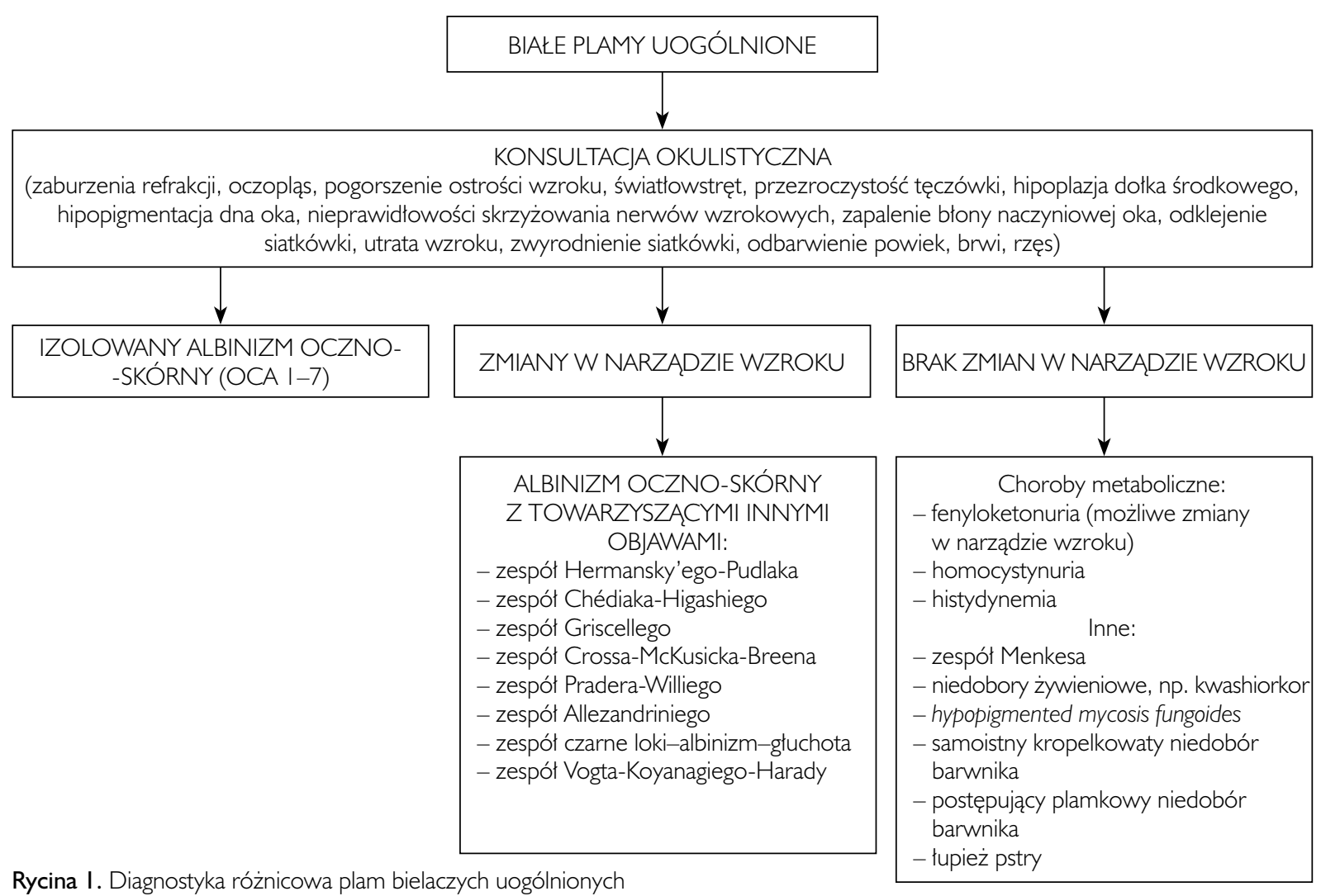




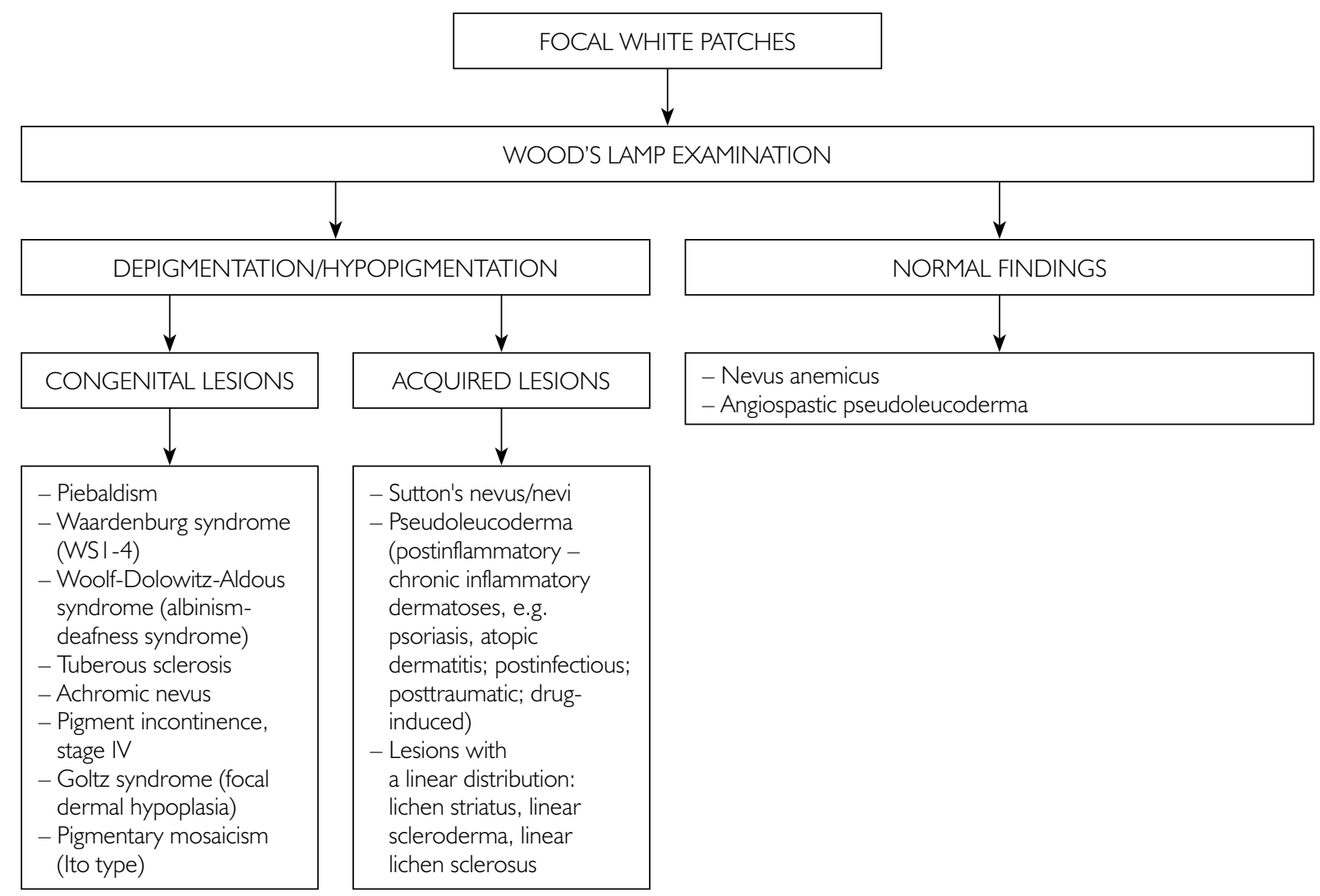

Figure 2. Differential diagnosis of focal vitiligo patches

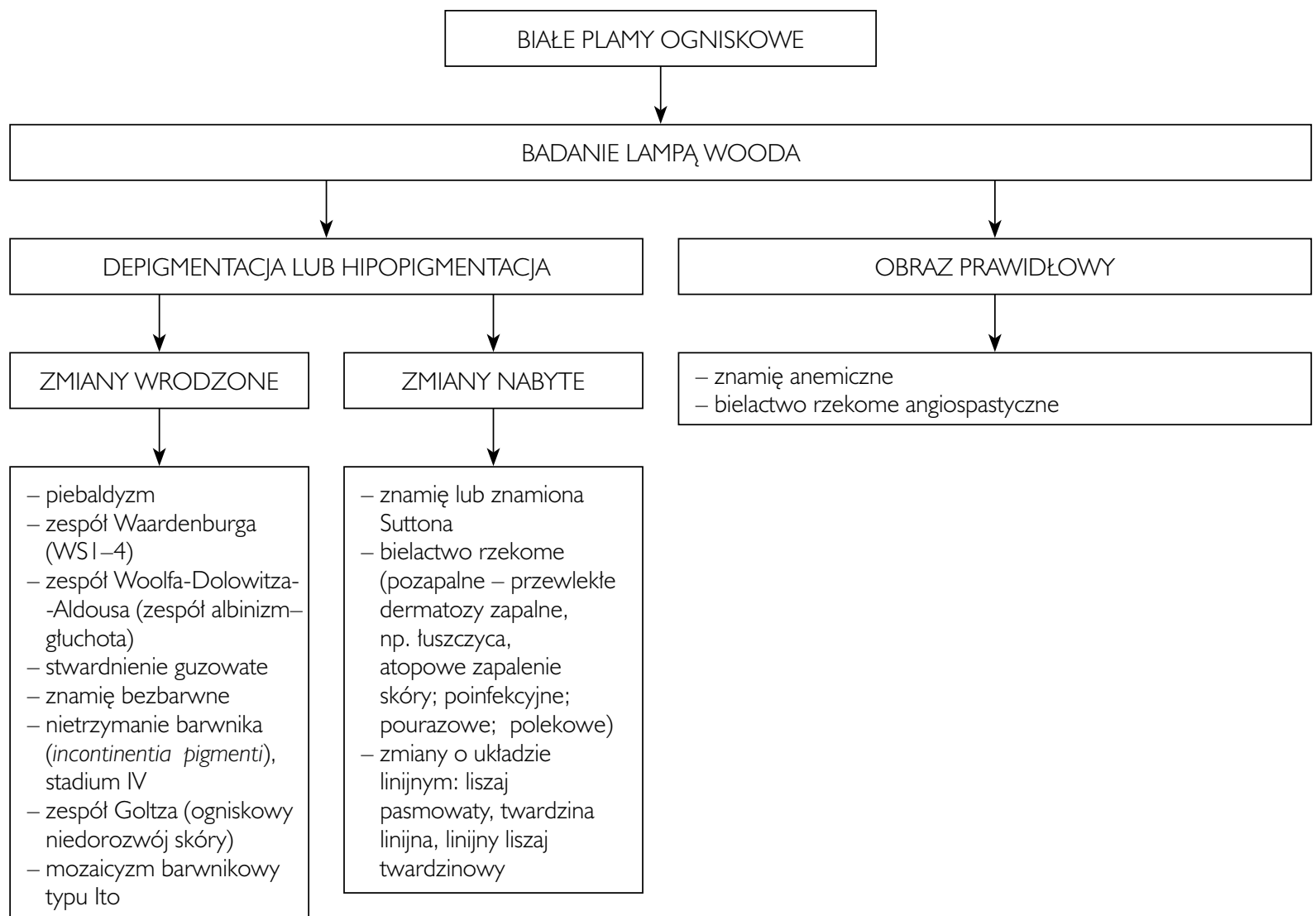

Rycina 2. Diagnostyka różnicowa plam bielaczych występujących ogniskowo 
Table I. Tests and consultations recommended in the diagnosis of acquired vitiligo

\begin{tabular}{|c|c|}
\hline Laboratory tests & Specialist consultations \\
\hline $\begin{array}{l}\text { - Antibodies against thyroglobulin (anti-TG) and peroxidase } \\
\text { (anti-TPO) } \\
\text { - TSH and other tests evaluating thyroid hormone activity (e.g. } \\
\text { anti-TSHR in patients with suspected Graves' disease) } \\
\text { - Other antibodies (only in patients with positive personal and/or } \\
\text { family history of autoimmune diseases and/or when additional } \\
\text { tests may suggest that vitiligo coexists with other autoimmune } \\
\text { disorders) }\end{array}$ & $\begin{array}{l}\text { - Endocrinological (in patients with suspected or detected } \\
\text { endocrine diseases, including autoimmune polyglandular } \\
\text { syndromes) } \\
\text { - Laryngological (to rule out hearing and balance disorders) } \\
\text { - Ophthalmological (to exclude ophthalmological disorders, } \\
\text { especially in patients with suspected oculocutaneous albinism) } \\
\text { - Psychiatric (in patients with symptoms of depressed mood } \\
\text { or impact on the quality of life) }\end{array}$ \\
\hline
\end{tabular}

Tabela I. Badania i konsultacje rekomendowane w diagnostyce bielactwa nabytego

\begin{tabular}{|c|c|}
\hline Badania laboratoryjne & Konsultacje specjalistyczne \\
\hline $\begin{array}{l}\text { - Przeciwciała przeciwko tyreoglobulinie (anty-TG) oraz } \\
\text { przeciwko peroksydazie (anty-TPO) } \\
\text { - TSH i inne badania oceniające aktywność hormonalną tarczycy } \\
\text { (np. anty-TSHR w przypadku podejrzenia choroby Gravesa- } \\
\text {-Basedowa) } \\
\text { - Inne przeciwciała (tylko w przypadku dodatniego } \\
\text { osobniczego i/lub rodzinnego wywiadu w kierunku chorób } \\
\text { autoimmunologicznych i/lub jeśli badania dodatkowe mogą } \\
\text { wskazywać na współistnienie bielactwa nabytego z innymi } \\
\text { zaburzeniami autoimmunologicznymi) }\end{array}$ & $\begin{array}{l}\text { - Endokrynologiczna (w przypadku podejrzenia lub wykrycia } \\
\text { chorób endokrynologicznych, w tym autoimmunologicznych } \\
\text { zespołów wielogruczołowych) } \\
\text { - Laryngologiczna (w celu wykluczenia zaburzeń słuchu } \\
\text { i równowagi) } \\
\text { - Okulistyczna (w celu wykluczenia zaburzeń okulistycznych, } \\
\text { szczególnie w razie podejrzenia albinizmu oczno-skórnego) } \\
\text { - Psychiatryczna (w przypadku objawów obniżonego nastroju } \\
\text { lub wpływu choroby na jakość życia) }\end{array}$ \\
\hline
\end{tabular}

tion and activity, clinical type of vitiligo, comorbidities and possible contraindications to treatment, and the patient's consent to a particular therapeutic modality. Currently available methods include topical and systemic treatment, phototherapy, laser therapy, surgery, cosmetic techniques, adjuvant treatment and psychotherapy. A number of publications have described combination therapies based on phototherapy and other treatment modalities targeted at accelerating the process of repigmentation [18-20]. Repigmentation of depigmented foci can be achieved by stimulating the migration of melanocytes from the hair follicles (follicular repigmentation) or, less commonly, from the periphery of depigmented patches (peripheral repigmentation) $[3,21]$. It should be noted that the vast majority of drugs for the treatment of vitiligo are used on an off-label basis, which requires the entry of relevant information in patient files and compliance with applicable regulations. The therapeutic recommendations are based on the current guidelines issued by other organizations, insights from the most recent literature and clinical experience of the authors.

\section{Topical treatment}

Topical treatment is recommended where vitiligo patches cover no more than $20 \%$ of the patient's body surface area.

Topical treatment with glucocorticoids or calcineurin inhibitors is recommended.

Potent topical glucocorticoids (class III according to the European classification) can be used in chil- postępowania zależy od wieku pacjenta, czasu trwania choroby, aktywności procesu chorobowego, typu klinicznego bielactwa nabytego, chorób współwystępujących, ewentualnych przeciwwskazań do leczenia oraz zgody pacjenta na określoną terapię. Dostępne obecnie metody obejmują: leczenie miejscowe, ogólne, fototerapię, laseroterapię, metody chirurgiczne, kosmetyczne, leczenie wspomagające oraz psychoterapię. W wielu publikacjach opisywano terapie łączone z wykorzystaniem fototerapii oraz innych form leczenia w celu przyspieszenia procesu repigmentacji [18-20]. Repigmentację ognisk chorobowych można uzyskać, wywołując migrację melanocytów z mieszków włosowych (repigmentacja przymieszkowa) bądź rzadziej z obwodu odbarwienia (repigmentacja obwodowa) [3, 21], Należy pamiętać, że większość leków używanych w terapii bielactwa nabytego jest stosowana poza wskazaniami rejestracyjnymi (off-label), co należy uwzględnić w dokumentacji chorych i postępować zgodnie z obowiązującymi w tym zakresie przepisami. W zaleceniach terapeutycznych uwzględniono obowiązujące zalecenia innych organizacji, dane $\mathrm{z}$ aktualnego piśmiennictwa oraz doświadczenia kliniczne autorów.

\section{Leczenie miejscowe}

Leczenie miejscowe znajduje zastosowanie w przypadkach, gdy plamy bielacze obejmują nie więcej niż 20\% powierzchni powłoki ciała.

Zaleca się stosowanie miejscowe glikokortykosteroidów lub inhibitorów kalcyneuryny.

Silne miejscowe glikokortykosteroidy (III klasa wg klasyfikacji europejskiej) mogą być stosowane u dzie- 
dren and adults with limited extrafacial vitiligo for a period not longer than 3 months once daily every day, or in a more recommended discontinuous treatment scheme for 15 days per month over a period not exceeding 6 months, with a strict assessment of treatment response based on photographic (preferably planimetric) documentation.

Facial lesions can be treated with topical calcineurin inhibitors yielding a similar efficacy. The best effects are achieved in the inflammatory phase of the disease.

Potent topical glucocorticoids are at least as effective as very potent glucocorticoids (class IV according to the European classification). Because of the lower risk of adverse reactions treatment should start with class III glucocorticoids.

Since absorption and systemic effects are a concern when topical glucocorticoids are applied to large areas of the skin (especially regions with thin skin and in children), mometasone furoate or methylprednisolone aceponate should be used on account of their limited systemic effects.

Topical calcineurin inhibitors can be used in children and adults with vitiligo as an alternative therapy to glucocorticoids, especially in the treatment of new and rapidly progressing vitiligo lesions. Calcineurin inhibitors have a superior safety profile to potent topical glucocorticoids, especially with respect to the possibility of causing skin atrophy.

Since the availability of double-blind placebo-controlled studies is limited, treatment with calcineurin inhibitors should be restricted to specific skin regions. Their use is indicated in particular on the face and neck.

According to recommendations, topical calcineurin inhibitors should be used twice a day. The induction therapy should last at least 6 months. Moderate exposure to sunlight is recommended during this period. If efficacy is demonstrated, prolonged treatment (even longer than 12 months) may be considered.

The use of other topical drugs (including vitamin $\mathrm{D}_{3}$ analogs) is not recommended either in monotherapy or combination therapy.

\section{Phototherapy}

Narrowband UVB radiation treatment (NB-UVB, $311 \mathrm{~nm}$ ) applied to the entire skin surface is indicated for generalized NSV. Total body irradiation is suggested for lesions involving more than $20 \%$ of the body area.

Focal NB UVB 311nm phototherapy (comb light) and targeted therapy (laser and non-laser light, $308 \mathrm{~nm}$ ) is indicated in patients with focal vitiligo, particularly new small-sized lesions occurring in children, in order to avoid adverse effects associated with ci i dorosłych na zmiany ograniczone, nieobejmujące skóry twarzy, przez okres nie dłuższy niż 3 miesiące raz na dobę codziennie lub w bardziej zalecanej terapii przerywanej przez $15 \mathrm{dni}$ w miesiącu nie dłużej niż 6 miesięcy, z dokładną oceną odpowiedzi na leczenie na podstawie dokumentacji fotograficznej (najlepiej planimetrycznej).

Zmiany na twarzy mogą być leczone $\mathrm{z}$ podobną skutecznością za pomocą miejscowych inhibitorów kalcyneuryny. Najlepsze efekty uzyskuje się w fazie zapalnej choroby.

Silne miejscowe glikokortykosteroidy są co najmniej tak samo skuteczne jak bardzo silne (IV klasa wg klasyfikacji europejskiej). Ze względu na mniejsze ryzyko wystąpienia działań niepożądanych zaleca się rozpoczynanie leczenia od glikokortykosteroidów klasy III.

Ze względu na ryzyko wchłaniania i działania ogólnoustrojowego miejscowo stosowanych glikokortykosteroidów na dużą powierzchnię skóry (szczególnie w przypadku cienkiej skóry oraz u dzieci) należy używać pirośluzanu mometazonu lub aceponianu metyloprednizolonu, które mają ograniczone działanie ogólnoustrojowe.

Miejscowe inhibitory kalcyneuryny mogą być stosowane $\mathrm{u}$ dzieci i dorosłych chorujących na bielactwo nabyte jako leczenie alternatywne w stosunku do glikokortykosteroidów, szczególnie w przypadku nowych i szybko postępujących zmian. Inhibitory kalcyneuryny mają lepszy profil bezpieczeństwa niż silne miejscowe glikokortykosteroidy, zwłaszcza w zakresie możliwości spowodowania atrofii skóry.

Ze względu na ograniczoną liczbę badań podwójnie zaślepionych, kontrolowanych placebo stosowanie inhibitorów kalcyneuryny powinno być ograniczone do wybranych regionów skóry. Szczególnie zalecane jest na obszarze twarzy i szyi.

Rekomendowane jest stosowanie miejscowych inhibitorów kalcyneuryny 2 razy dziennie. Leczenie inicjujące powinno trwać co najmniej 6 miesięcy. W tym czasie zalecana jest umiarkowana ekspozycja na światło słoneczne. Jeśli leczenie jest efektywne, można włączyć terapię wydłużoną (nawet ponad 12 miesięcy).

Stosowanie innych preparatów miejscowych (m.in. analogów witaminy $\mathrm{D}_{3}$ ) nie jest rekomendowane ani w monoterapii, ani w terapii łączonej.

\section{Fototerapia}

Terapia NB UVB 311 nm (na całą skórę) jest stosowana w leczeniu NSV typu uogólnionego. Naświetlanie całej powierzchni skóry rekomenduje się w przypadku zmian zajmujących ponad $20 \%$ jej powierzchni.

Fototerapia NB UVB 311 nm ogniskowa (lampa grzebień) oraz celowana (laserowa i nielaserowa 
total body irradiation or in cases where such therapy is contraindicated. The method can also be used as monotherapy or in combination with topical drugs.

PUVA is indicated as second-line therapy, primarily in adults with generalized NSV. Compared with NB UVB 311nm, it is less effective and carries a higher risk of short- and long-term adverse effects.

In the case of PUVA treatment with topical psoralen solutions (PUVA-bath), very low concentrations of psoralens (maximum $0.01 \%$ ) are recommended.

Phototherapy should be considered ineffective if no repigmentation (mainly follicular) is observed during the initial 3 months of treatment or the degree of repigmentation is less than $25 \%$ after 6 months of treatment.

Phototherapy should be continued for as long as it is effective, making sure not to exceed the total dose of 2,000 J/ $\mathrm{cm}^{2}$ of the skin surface (PUVA), or for a maximum of 2 years (NB UVB $311 \mathrm{~nm}$ therapy). Maintenance phototherapy is not recommended, but regular follow-up examinations are suggested for detecting possible recurrence of depigmentation.

During periods of high insolation phototherapy with artificial light sources should be interrupted and replaced with heliotherapy.

\section{Combination therapies}

Topical glucocorticoids and phototherapy

The anti-inflammatory properties of glucocorticoids may contribute to a decrease in the total UV dose administered during combination therapy with UV treatment, particularly in patients with new and active lesions. Despite the lack of prospective studies, combination therapy with topical glucocorticoids and NB UVB $311 \mathrm{~nm}$ or $308 \mathrm{~nm}$ laser/lamp may be useful in the treatment of vitiligo patches in challenging locations, e.g. on the elbows and knees, and in other areas where the skin adheres directly to the joints and/ or bones. In such cases, potent topical glucocorticoids should be used once daily (for 3 of 4 weeks) during the initial three months of phototherapy.

\section{Topical calcineurin inhibitors and phototherapy}

A number of studies have found that combination therapy with topical calcineurin inhibitors and phototherapy demonstrates superior efficacy to each therapeutic modality used separately. A growing number of reports suggest that this method of management is safe for the patients, however results of long-term studies are still needed to rule out the carcinogenic effect.

\section{Phototherapy and surgical methods}

NB UVB $311 \mathrm{~nm}$ or PUVA phototherapy (according to generally recognized principles) should be
$308 \mathrm{~nm}$ ) jest wskazana w przypadku bielactwa nabytego ogniskowego, zwłaszcza małych, nowych zmian występujących $\mathrm{u}$ dzieci w celu uniknięcia działań niepożądanych związanych z naświetlaniem całej powierzchni skóry lub w przypadku istnienia przeciwwskazań to takiej terapii. Metoda ta może być stosowana w monoterapii lub w leczeniu łączonym z preparatami miejscowymi.

Metoda PUVA jest stosowana jako leczenie drugiego wyboru, głównie $\mathrm{u}$ dorosłych z NSV typu uogólnionego. W porównaniu z NB UVB 311 nm jest mniej efektywna i obarczona większym ryzykiem wystąpienia objawów niepożądanych krótko- i długoterminowych.

W przypadku leczenia PUVA z miejscowo stosowanymi roztworami psoralenów (PUVA-bath) zaleca się bardzo małe stężenia psoralenów (maksymalnie 0,01\%).

Fototerapię należy uznać za nieefektywną, jeżeli w czasie pierwszych 3 miesięcy leczenia nie zaobserwowano repigmentacji (głównie przymieszkowej) lub stopień repigmentacji był mniejszy niż $25 \%$ po 6 miesiącach terapii.

Fototerapię kontynuuje się do czasu, gdy jest efektywna, pamiętając, żeby nie przekroczyć dawki całkowitej $2000 \mathrm{~J} / \mathrm{cm}^{2}$ powierzchni skóry (leczenie PUVA) lub maksymalnie 2 lat terapii NB UVB $311 \mathrm{~nm}$. Nie zaleca się fototerapii podtrzymującej, a jedynie regularne wizyty kontrolne w celu wczesnego wykrycia ewentualnego nawrotu depigmentacji.

W okresie dużego nasłonecznienia proponuje się przerwanie fototerapii sztucznymi źródłami światła i zastąpienie jej helioterapią.

\section{Terapie łączone}

\section{Miejscowe glikokortykosteroidy i fototerapia}

Właściwości przeciwzapalne glikokortykosteroidów mogą się przyczynić do zmniejszenia całkowitej dawki promieniowania ultrafioletowego podczas terapii łączonej z UV, zwłaszcza w przypadku nowych i aktywnych zmian chorobowych. Pomimo braku badań prospektywnych terapia łączona miejscowymi glikokortykosteroidami i NB UVB $311 \mathrm{~nm}$ lub laserem, lub lampą 308 nm może być przydatna w leczeniu plam bielaczych w trudnych lokalizacjach, takich jak łokcie, kolana i inne miejsca, w których skóra przylega bezpośrednio do stawów i/lub kości. W takich przypadkach silne miejscowe glikokortykosteroidy należy stosować raz dziennie (przez 3 z 4 tygodni) podczas pierwszych 3 miesięcy fototerapii.

\section{Miejscowe inhibitory kalcyneuryny i fototerapia}

Wiele badań potwierdza, że leczenie łączone miejscowymi inhibitorami kalcyneuryny $z$ fototerapią jest bardziej efektywne niż każda z tych metod stosowana oddzielnie. Coraz większa liczba doniesień suge- 
used after performing the surgical procedures indicated for vitiligo in order to achieve optimum results of surgical treatment. Phototherapy should be provided until visible repigmentation progression (preferably based on photographic or planimetric documentation).

\section{Oral minipulse therapy with glucocorticoids}

Oral minipulse therapy with glucocorticoids can be used in the treatment of active, rapidly progressive lesions in patients with non-segmental vitiligo in order to halt the progression of the disease (rather than achieve repigmentation).

Oral minipulse treatment should start from low weekend doses of glucocorticoids (dexamethasone at a daily dose of 2-5 mg for two consecutive days of the week), which ensures a good safety profile.

The optimal duration of oral minipulse therapy with glucocorticoids ranges from 3 to 6 months.

\section{Surgical treatment}

An established surgical technique used for the treatment of vitiligo is suction blister epidermal grafting.

Surgical treatment is recommended as the first-line therapy for vitiligo patches located on the dorsal surfaces of hands and feet and in any other location after the failure of other treatment methods.

Surgery may be considered exclusively in patients with stable disease (no new vitiligo lesions and no progression of existing lesions for 6 months).

Polish dermatology centers offering the surgical treatment of vitiligo: Department of Dermatology, Sexually Transmitted Diseases and Clinical Immunology, Ludwik Rydygier Collegium Medicum in Bydgoszcz, Nicolaus Copernicus University in Toruń; Chair and Department of Dermatology, Sexually Transmitted Diseases and Clinical Immunology, University of Warmia and Mazury in Olsztyn.

\section{Other therapeutic modalities}

There are a few literature reports addressing the possibility of achieving an improvement in the treatment of vitiligo with other therapeutic methods, including cyclosporins [22], methotrexate [23], azathioprine [24], topical mycophenolate mofetil [25] or inhibitors of Janus kinases (JAK) [26], and other immunosuppressive drugs. The potential benefit of using these therapeutic modalities can be considered in individual cases.

\section{Camouflage}

Camouflage techniques to conceal vitiligo lesions are indicated especially in patients with impaired quality of life. Camouflage is recommended in patients in whom ruje, że jest to postępowanie bezpieczne dla pacjenta, jednak wciąż oczekujemy na długoterminowe wyniki badań dotyczące efektu kancerogennego.

\section{Fototerapia i metody chirurgiczne}

Po wykonaniu procedur chirurgicznych stosowanych w leczeniu bielactwa nabytego należy zastosować fototerapię NB UVB 311 nm lub PUVA (według ogólnie przyjętych zasad) w celu uzyskania optymalnych wyników leczenia zabiegowego. Fototerapię prowadzi się do czasu widocznej progresji repigmentacji (najlepiej opierając się na dokumentacji fotograficznej, planimetrycznej).

\section{Doustne minipulsy glikokortykosteroidowe}

Doustna terapia glikokortykosteroidami w postaci minipulsów może być stosowana w leczeniu aktywnych, szybko postępujących zmian chorobowych w przebiegu NSV w celu zahamowania progresji choroby (a nie uzyskania repigmentacji).

Minipulsy doustne należy rozpocząć od małych dawek weekendowych glikokortykosteroidów (2-5 mg dziennie deksametazonu przez 2 kolejne dni w tygodniu), co zapewnia duży profil bezpieczeństwa.

Optymalny czas trwania terapii doustnymi minipulsami glikokortykosteroidowymi wynosi 3-6 miesięcy.

\section{Leczenie chirurgiczne}

Metodą chirurgiczną stosowaną w leczeniu bielactwa nabytego jest bezpośredni przeszczep pokryw pęcherzy uzyskanych metodą podciśnieniową, tzw. suction blister.

Leczenie chirurgiczne jest metodą pierwszego wyboru w przypadku plam bielaczych zlokalizowanych na grzbietach rąk i stóp oraz w każdej innej lokalizacji w przypadku nieskuteczności innych terapii.

Do leczenia chirurgicznego mogą być kwalifikowani chorzy wyłącznie ze stabilną postacią choroby (6 miesięcy bez powiększania się obecnych plam bielaczych i pojawiania się nowych).

Leczenie chirurgiczne bielactwa nabytego prowadzone jest w Katedrze i Klinice Dermatologii, Chorób Przenoszonych Drogą Płciową i Immunodermatologii Collegium Medicum im. Ludwika Rydygiera w Bydgoszczy Uniwersytetu Mikołaja Kopernika w Toruniu oraz w Katedrze i Klinice Dermatologii, Chorób Przenoszonych Drogą Płciową i Immunologii Klinicznej Uniwersytetu Warmińsko-Mazurskiego w Olsztynie.

\section{Inne metody leczenia}

Znane są nieliczne dane z piśmiennictwa dotyczące uzyskania poprawy w leczeniu bielactwa nabytego za pomocą innych metod terapeutycznych, w tym cyklosporyny [22], metotreksatu [23], azatiopryny [24], miejscowo stosowanego mykofenolanu mofety- 
previous treatment has failed to bring a satisfactory outcome, have contraindications or have experienced side effects of repigmentation therapy, and in patients who do not consent to treatment, while not being eligible for the depigmentation treatment of "islands" of healthy skin. Camouflage can also be used by patients during repigmentation therapy, provided that the camouflage technique used does not hinder treatment.

\section{Psychological/psychiatric support}

DLQI assessment is recommended in every patient. Based on the results, the need for psychological/psychiatric support should be considered.

\section{Depigmentation of remaining normal skin}

Depigmentation therapy for vitiligo should be considered only in patients with "islands" of healthy skin not exceeding $20 \%$ of the total skin area. The de- lu [25] lub inhibitorów kinaz janusowych (JAK) [26] oraz innych leków o działaniu immunosupresyjnym. W indywidualnych przypadkach można rozważyć zastosowanie tych metod.

\section{Kamuflaż}

Kamuflowanie plam bielaczych jest szczególnie wskazane u osób z obniżoną jakością życia. Z kamuflażu powinni korzystać pacjenci, którzy nie uzyskali zadowalających efektów dotychczasowego leczenia, mają przeciwwskazania lub pojawiły się u nich działania niepożądane terapii repigmentacyjnej, a także chorzy, którzy nie wyrażają zgody na terapię, a jednocześnie nie kwalifikują się do leczenia odbarwiającego „wysp” zdrowej skóry. Z kamuflażu mogą również korzystać chorzy w trakcie terapii repigmentacyjnej, jeśli zastosowana technika kamuflażu nie utrudnia prowadzenia leczenia.

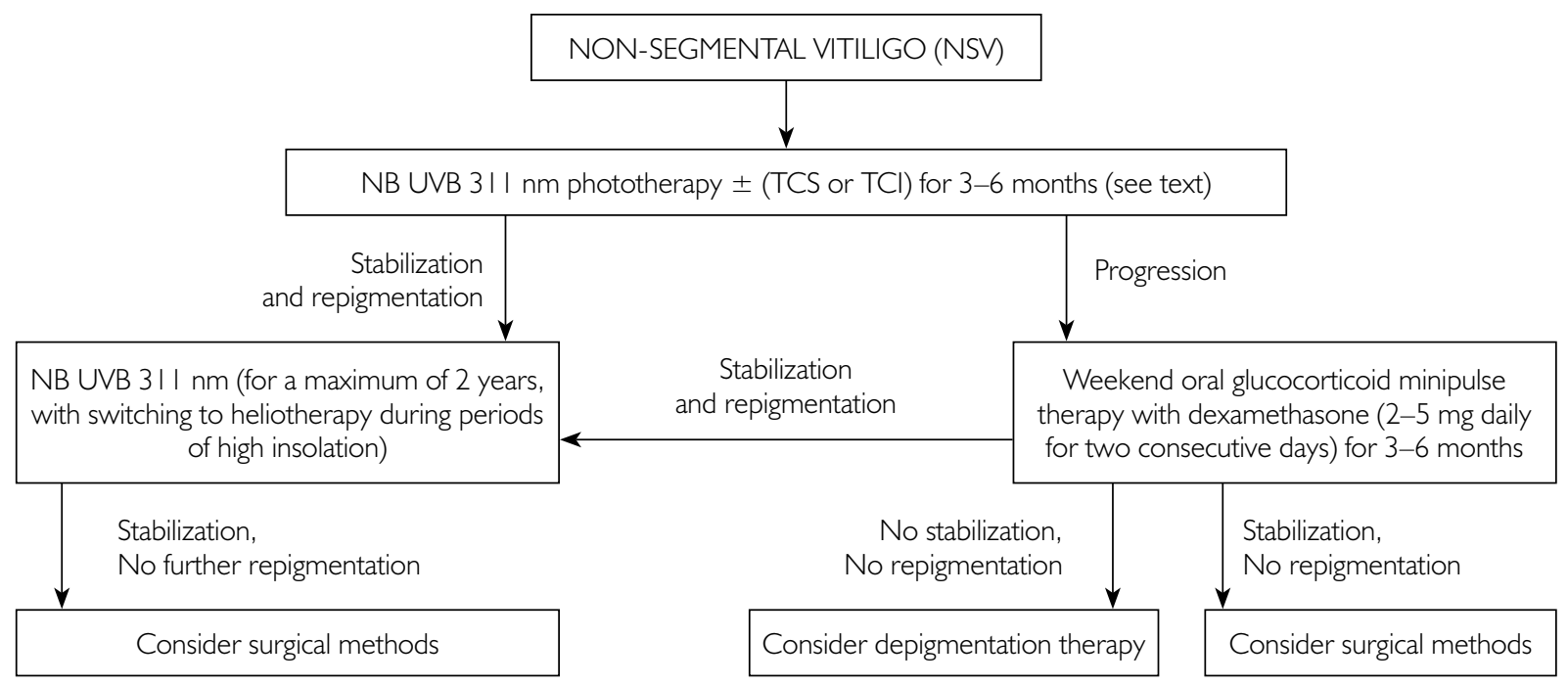

Figure 3. Non-segmental vitiligo - management scheme

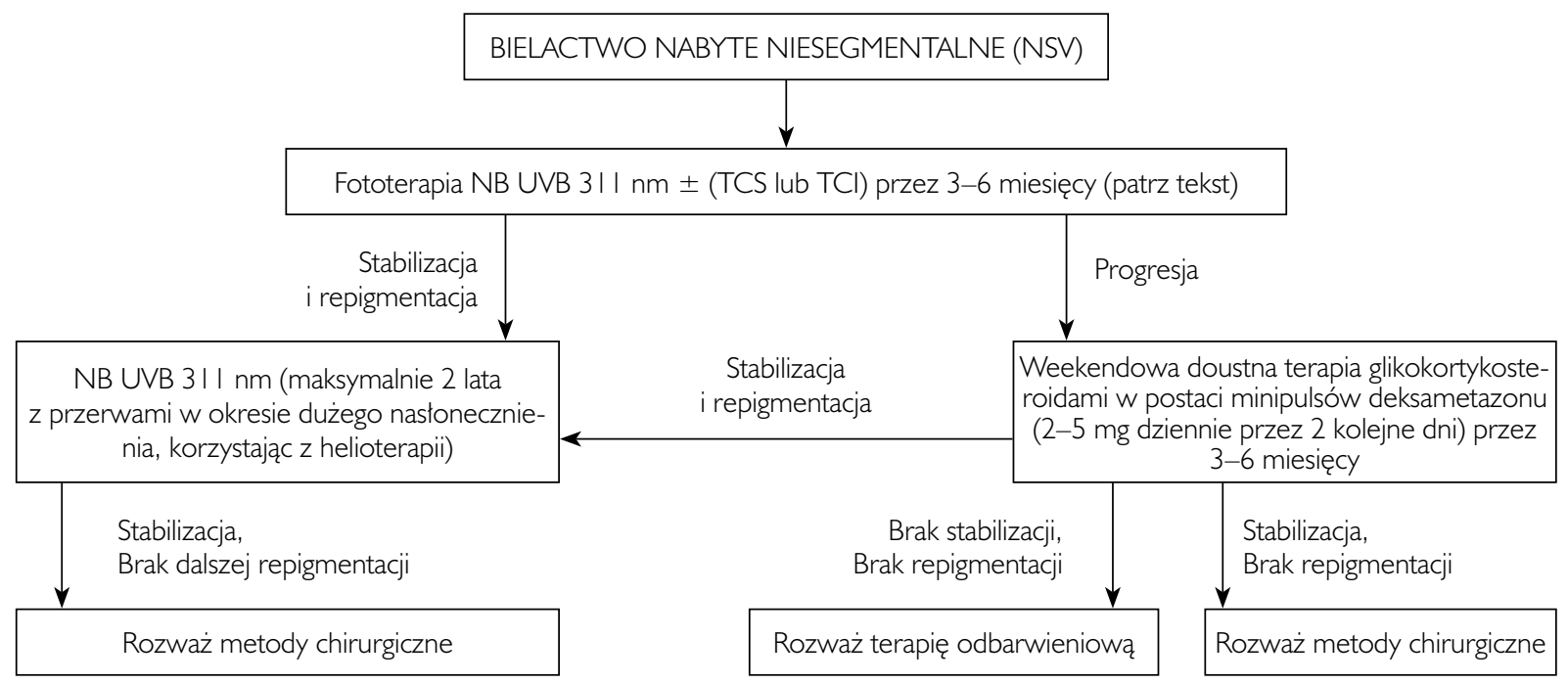

Rycina 3. Bielactwo nabyte niesegmentalne - schemat postępowania 
pigmenting agent is monobenzylether of hydroquionone. The use of the Q-switched ruby laser (either in monotherapy or combination therapy with methoxyphenol) has also been proposed.

Therapeutic algorithms for the management of vitiligo are presented in figures 3 and 4 .

\section{New modalities in the treatment of vitiligo}

Recently, in the therapy of adults and children with vitiligo, there has been a shift away from the traditionally dominant PUVA method as the first-line treatment of patients with vitiligo $[27,28]$. Studies

\section{Wsparcie psychologiczne lub psychiatryczne}

Rekomendowane jest wypełnienie przez każdego pacjenta ankiety DLQI. Na podstawie jej wyniku należy podjąć decyzję o konieczności konsultacji psychologicznej lub psychiatrycznej.

\section{Odbarwienie wysp zdrowej skóry}

Terapii odbarwieniowej powinni być poddani jedynie pacjenci z wyspami zdrowej skóry o obszarze całkowitym nieprzekraczającym $20 \%$ jej powierzchni. Środkiem depigmentującym jest eter monobenzylo-

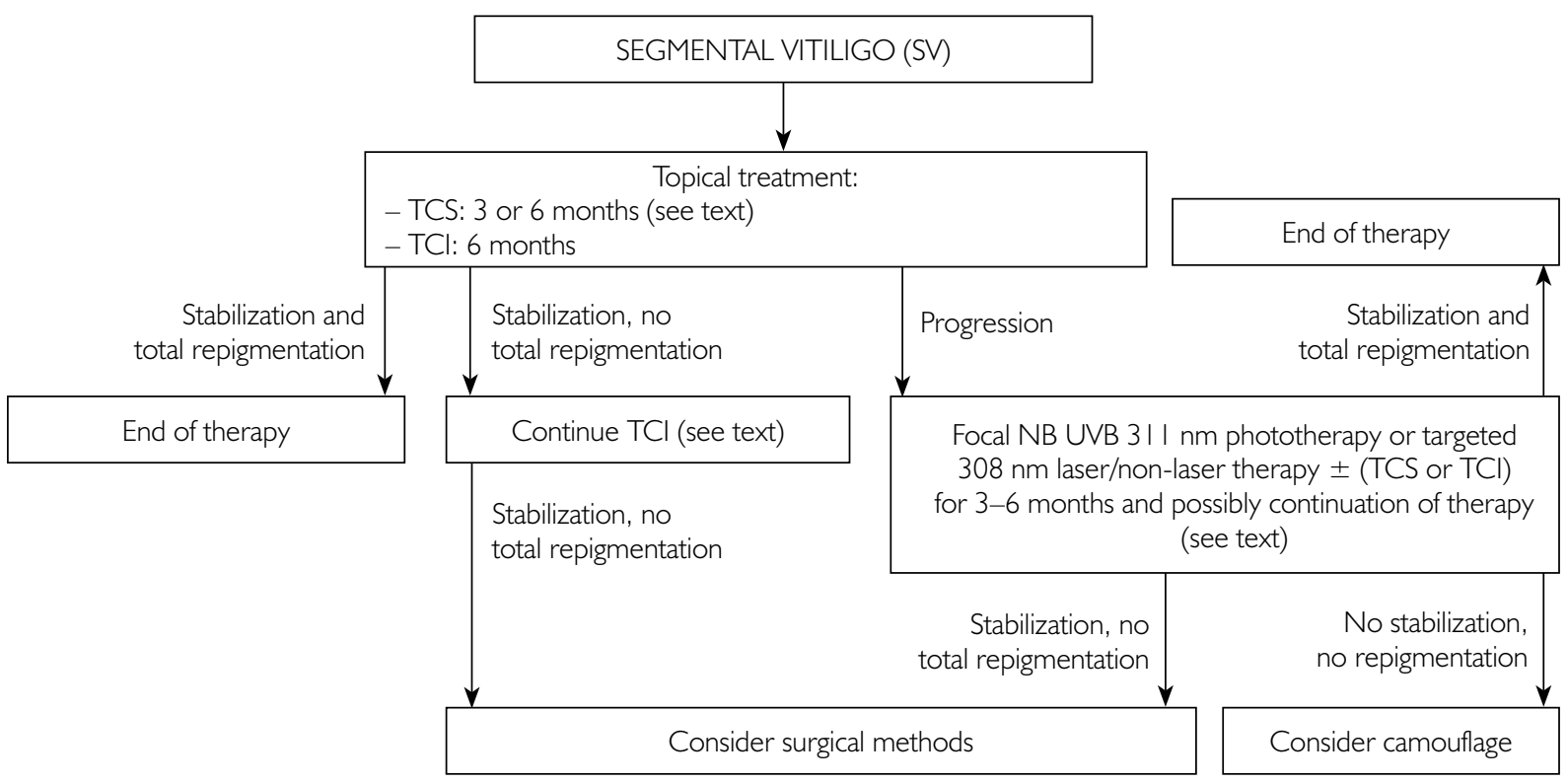

Figure 4. Segmental vitiligo - management scheme

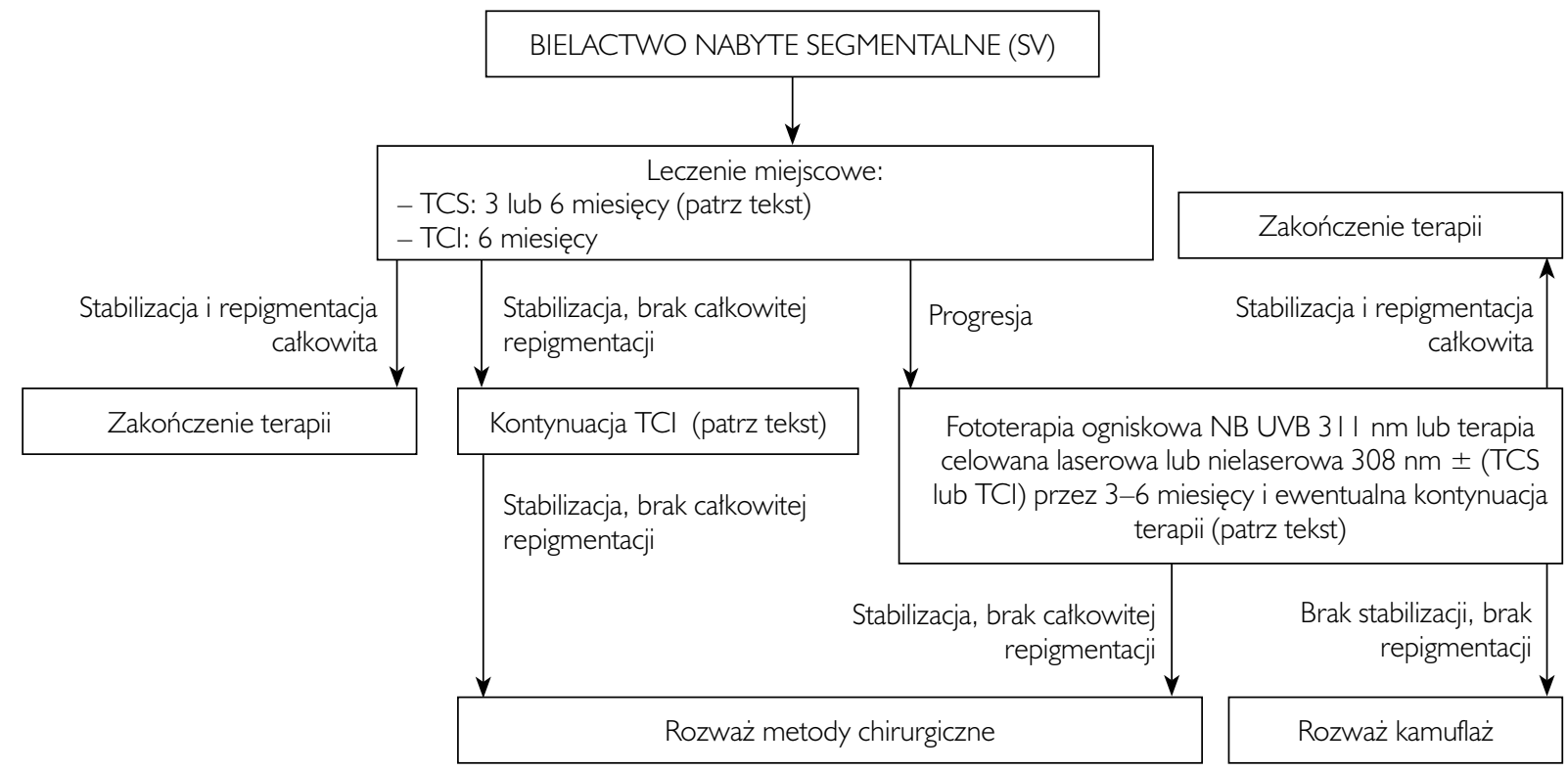

Rycina 4. Bielactwo nabyte segmentalne - schemat postępowania 
over the past years show that NB UVB 311 nm therapy produces better therapeutic results with a more favorable safety profile compared to PUVA [29], and demonstrates superior efficacy to UVA1 [30]. Currently, other laser therapy methods, not described in these recommendations, are also being considered for their potential future applications in the treatment of vitiligo. Clinical trials are currently under way to verify the benefit of using drugs belonging to different therapeutic classes and exhibiting various mechanisms of action, such as intralesional injections of triamcinolone, apremilast, JAK inhibitors, latanoprost and bimatoprost.

It needs to be stressed that physicians make therapeutic decisions on a case-by-case basis, after considering all indications and contraindications to different treatment modalities, and specific factors present in a given patient.

\section{CONFLICT OF INTEREST}

The authors declare no conflict of interest. wy hydrochinonu. Można również zastosować rubinowy laser Q-switched (w monoterapii lub w terapii łączonej z metoksyfenolem).

Algorytmy terapeutyczne dla bielactwa nabytego przedstawiono na rycinach 3 i 4 .

\section{Nowe kierunki w leczeniu}

W leczeniu dorosłych i dzieci z bielactwem nabytym odchodzi się obecnie od dominującej jeszcze niedawno metody PUVA jako terapii pierwszego wyboru [27, 28]. Wyniki badań z ostatnich lat wykazują, że leczenie NB UVB $311 \mathrm{~nm}$ daje lepsze efekty przy korzystniejszym profilu bezpieczeństwa w stosunku do metody PUVA [29] i jest skuteczniejsze niż UVA1 [30]. Obecnie rozważa się możliwość wykorzystania w przyszłości innych niż wymienione w tym opracowaniu metod laseroterapii bielactwa nabytego. Trwają badania kliniczne weryfikujące zastosowanie leków z różnych grup terapeutycznych i o różnym mechanizmie działania, w tym iniekcji doogniskowych triamcynolonu, apremilastu, inhibitorów JAK, latanoprostu i bimatoprostu.

Należy podkreślić, że w każdym przypadku lekarz podejmuje decyzję terapeutyczną po uwzględnieniu wskazań i przeciwwskazań do stosowania poszczególnych metod oraz uwarunkowań dotyczących danego pacjenta.

\section{KONFLIKT INTERESÓW}

Autorzy nie zgłaszają konfliktu interesów.

\section{References \\ Piśmiennictwo}

1. Placek W., Czajkowski R., Chabior A: Bielactwo nabyte. Dermatol Prakt 2009, 3, 9-18.

2. Mahmoud B.H., Hexsel C.L., Hamzavi I.H.: An update on new and emerging options for the treatment of vitiligo. Skin Therapy Lett 2008, 13, 1-6.

3. Misterska M., Szulczyńska-Gabor J., Żaba R.: Etiopatogeneza, obraz kliniczny i leczenie bielactwa. Postep Dermatol Alergol 2009, 25, 212-223.

4. Schwartz R.A., Janniger C.K.: Vitiligo. Cutis 1997, 60, 239-244.

5. Ezzedine K., Lim H.W., Suzuki T., Katayama I., Hamzavi I., Lan C.C., et al.: Revised classification/nomenclature of vitiligo and related issues: the Vitiligo Global Issues Consensus Conference. Pigment Cell Melanoma Res 2012, 25, E1-13.

6. Taieb A., Picardo M.: Clinical practice. Vitiligo. N Engl J Med 2009, 360, 160-169.

7. Pajvani U., Ahmad N., Wiley A., Levy R.M., Kundu R., Mancini A.J., et al.: The relationship between family medical history and childhood vitiligo. J Am Acad Dermatol 2006, 55, 238-244.

8. Mazereeuw-Hautier J., Harper J.: Vitiligo. In: Textbook of Pediatric Dermatology. ${ }^{\text {nd }}$ ed. J. Harper, A. Oranje, N. Prose (eds.). Blackwell Publishing Ltd, Oxford 2006.

9. Palit A., Inamadar A.C.: Childhood vitiligo. Indian J Dermatol Venereol Leprol 2012, 78, 30-41.

10. Handa S., Dogra S.: Epidemiology of childhood vitiligo: a study of 625 patients from North India. Pediatr Dermatol 2003, 20, 207-210.

11. Czajkowski R., Męcińska-Jundziłł K.: Current aspects of vitiligo genetics. Postep Dermatol Alergol 2014, 31 , $247-255$.

12. Sá D.C., Festa C. Neto.: Inflammasomes and dermatology. An Bras Dermatol 2016, 91, 566-578.

13. Pegum J.S.: Vitiligo. Br J Dermatol 1996, 134, 373.

14. Moretti S., Spallanzani A., Amato L., Hautmann G., Gallerani I., Fabiani M., et al.: New insights into the pathogenesis of vitiligo: imbalance of epidermal cytokines at sites of lesions. Pigment Cell Res 2002, 15, 87-92.

15. Le Poole I.C., van den Wijngaard R.M., Westerhof W., Dutrieux R.P., Das P.K.: Presence or absence of melanocytes in vitiligo lesions: an immunohistochemical investigation. J Invest Dermatol 1993, 100, 816-822. 
16. Le Poole I.C., van den Wijngaard R.M., Westerhof W., Das P.K.: Tenascin is overexpressed in vitiligo lesional skin and inhibits melanocyte adhesion. Br J Dermatol 1997, 137, 171-178.

17. Tobin D.J., Swanson N.N., Pittelkow M.R., Peters E.M., Schallreuter K.U.: Melanocytes are not absent in lesional skin of long duration vitiligo. J Pathol 2000, 191, 407-416.

18. Czajkowski R., Pokrywczynska M., Placek W., Zegarska B., Tadrowski T., Drewa T.: Transplantation of cultured autologous melanocytes: hope or danger? Cell Transplant 2010, 19, 639-643.

19. Bae J.M., Jung H.M., Hong B.Y., Lee J.H., Choi W.J., Lee J.H., et al.: Phototherapy for vitiligo: a systematic review and metaanalysis. JAMA Dermatol 2017, 153, 666-674.

20. Iwanowski T., Szlązak P., Rustowska A., Sokołowska-Wojdyło M.: Efficacy of suction blister epidermal grafting with concomitant phototherapy in vitiligo treatment. Adv Dermatol Allergol 2018, 35, 592-598.

21. Yang K., Xiong X., Pallavi G., Ling Y., Ding F., Duan W., et al.: The early repigmentation pattern of vitiligo is related to the source of melanocytes and by the choice of therapy: a retrospective cohort study. Int J Dermatol 2018, 57, 324-331.

22. Mutalik S., Shah S., Sidwadkar V., Khoja M.: Efficacy of cyclosporine after autologous noncultured melanocyte transplantation in localized stable vitiligo - a pilot, open label, comparative study. Dermatol Surg 2017, 43, $1339-1347$.

23. Abdelmaksoud A.: Methotrexate for treatment of vitiligo. Dermatol Ther 2017; 30: doi: 10.1111/dth.12532.

24. Radmanesh M., Saedi K.: The efficacy of combined PUVA and low-dose azathioprine for early and enhanced repigmentation in vitiligo patients. J Dermatolog Treat 2006, 17, 151-153.

25. Handjani F., Aghaei S., Moezzi I., Saki N.: Topical mycophenolate mofetil in the treatment of vitiligo: a pilot study. Dermatol Pract Concept 2017, 7, 31-33.

26. Rothstein B., Joshipura D., Saraiya A., Abdat R., Ashkar H., Turkowski Y.: Treatment of vitiligo with the topical Janus kinase inhibitor ruxolitinib. J Am Acad Dermatol 2017, 76, 1054-1060.

27. Tallab T., Joharji H., Bahamdan K., Karkashan E., Mourad M., Ibrahim K.: Response of vitiligo to PUVA therapy in Saudi patients. Int J Dermatol 2005, 44, 556-558.

28. Wolska H.: Fototerapia (UV) w dermatologii. Czelej, Lublin, 2012.

29. Shenoi S.D., Prabhu S.: Photochemotherapy (PUVA) in psoriasis and vitiligo. Indian J Dermatol Venereol Leprol 2014, 80, 497-504.

30. El-Zawahry B.M., Elmasry M.F., Ragab A.: The role of long-wavelength ultraviolet A1 (UVA1) in acral vitiligo. J Cosmet Dermatol. 2018 Oct 29. doi: 10.1111/jocd.12808.

Received: 27.01.2019

Accepted: 28.02.2019

Otrzymano: 27.01.2019 r.

Zaakceptowano: 28.02.2019 r.

How to cite this article

Czajkowski R., Placek W., Flisiak I., Krasowska D., Maj J., Marchlewicz M., Reich A., Wolska H., Rudnicka L.: Vitiligo. Diagnostic and therapeutic recommendations of the Polish Dermatological Society. Dermatol Rev/Przegl Dermatol 2019, $106,1-15$. DOI: https://doi.org/10.5114/dr.2019.83440. 